\title{
A CLIMATIC STUDY OF AN URBAN GREEN SPACE: THE GULBENKIAN PARK IN LISBON (PORTUGAL)*
}

\author{
HENRIQUE ANDRADE ${ }^{1}$ \\ RUTE VIEIRA ${ }^{2}$
}

\begin{abstract}
Measurements of various climatic parameters were carried out in an average-sized green space in the centre of Lisbon (the Fundação Calouste Gulbenkian Park). The aims consisted of assessing the thermal differentiation between the park and the surrounding built-up area and analysing the microclimatic patterns within the park itself. The main results demonstrate that the park is cooler than the built-up area in all the seasons and both during the daytime and at night, but especially so in the daytime during the summer. The most significant microclimatic contrasts were found to occur with respect to solar radiation and mean radiant temperature, with consequences upon the level of thermal comfort. The structure of the vegetation was also found to have a significant microclimatic influence, since the reduction in the level of incident solar radiation brought on by the presence of groups of trees was much larger than that associated with isolated trees.
\end{abstract} radiation

Key words: Urban climate, green areas, microclimate, thermal comfort, solar

Resumo - ESTUdo CLIMÁtico DE UM ESPAÇO VERDE DE LisboA: O JARDiM DA FundaÇão Calouste Gulbenkian. Foram efectuadas medições de diferentes parâmetros climáticos num espaço verde de dimensões médias no centro de Lisboa (no Parque da Gulbenkian). Os objectivos foram medir a diferença térmica entre o parque e a área urbana envolvente e analisar os padrões microclimáticos dentro do próprio parque. Os principais resultados demonstram que o parque é mais fresco do que a área construída em todas as estações, tanto durante o dia como durante a noite, mas especialmente no Verão durante o dia. O contraste microclimatico mais significativo foi encontrado em relação à radiação solar e à temperatura radiativa média, com consequências no nível de conforto térmico. A estrutura da vegetação também demonstrou ter uma influência microclimática significativa, com maior redução da radiação solar incidente sob grupos de árvores do que sob árvores isoladas.

* Recebido: 07/03/2007. Revisto: 13/11/2007. Aceite: 20/12/2007.

1 Professor Auxiliar da Faculdade de Letras da Universidade de Lisboa. Investigador do Centro de Estudos Geográficos. E-mail: handrade@f.ul.pt

2 Investigadora do Centro de Estudos Geográficos. E-mail: rute@fl.ul.pt 
Palavras-chave: Clima urbano, áreas verdes, microclima, conforto térmico, radiação solar.

Résumé - Étude ClimatiQue D’un des ESPACES VERTS DE LisbonNe : LE PARC de la Fondation Gulbenkian. Dans cet espace vert de dimension moyenne, on a mesuré divers paramètres climatiques, afin d'apprécier la différence thermique existant entre le parc et l'espace urbain périphérique, et d'analyser la répartition des microclimats à l'intérieur du parc. On observe que celui-ci est plus frais que l'aire construite périphérique, en toute saison et de jour comme de nuit, mais surtout pendant les journées estivales. Le contraste microclimatique le plus significatif affecte la radiation solaire et la température radiative moyenne au soleil, ce qui modifie le niveau de confort thermique. La structure de la végétation a aussi une influence significative, la radiation solaire étant davantage réduite sous un groupe d'arbres que sous un arbre isolé.

Mots clés: Climat urbain, espace vert, microclimat, confort thermique, radiation solaire.

\section{INTRODUCTION}

In biophysical, social and cultural terms, urban green spaces play a very important role in improving the quality of life and in enabling the cities to project an attractive and competitive image (Givoni, 1998; Santamouris, 2001; G.L.A., 2001; Baycan-Levent, et al. 2002). From the biophysical point of view, green spaces have been acknowledged as bringing about numerous climatic, hydrological and biological benefits. In a context of increasing urban and global environmental degradation, these functions assume growing importance.

This article presents the results of a climatic study undertaken in the Fundação Calouste Gulbenkian Park (henceforth GP), which is located in Lisbon (fig. 1). The choice of this park as a case-study was made in accordance with several criteria: it is a medium-sized green space $(8.5 \mathrm{ha})$ located in the central part of the city of Lisbon, which renders it particularly interesting as a "case-study"; and it is a relatively flat area, which ensures that the results do not depend on the topography and can therefore be more easily generalized.

The goals of this study were twofold: a) to measure the thermal differentiation between the park and the neighbouring built-up area (local scale) both during the daytime and at night; and $b$ ) to analyse the microclimatic patterns within the green space itself during the daytime.

Although often mentioned in passing, the climatic benefits of urban green spaces are rarely accounted for, or checked against actual empirical data. In order to set the stage for the presentation of the results of this study, the following section summarises some of the previously existing research on this topic. 


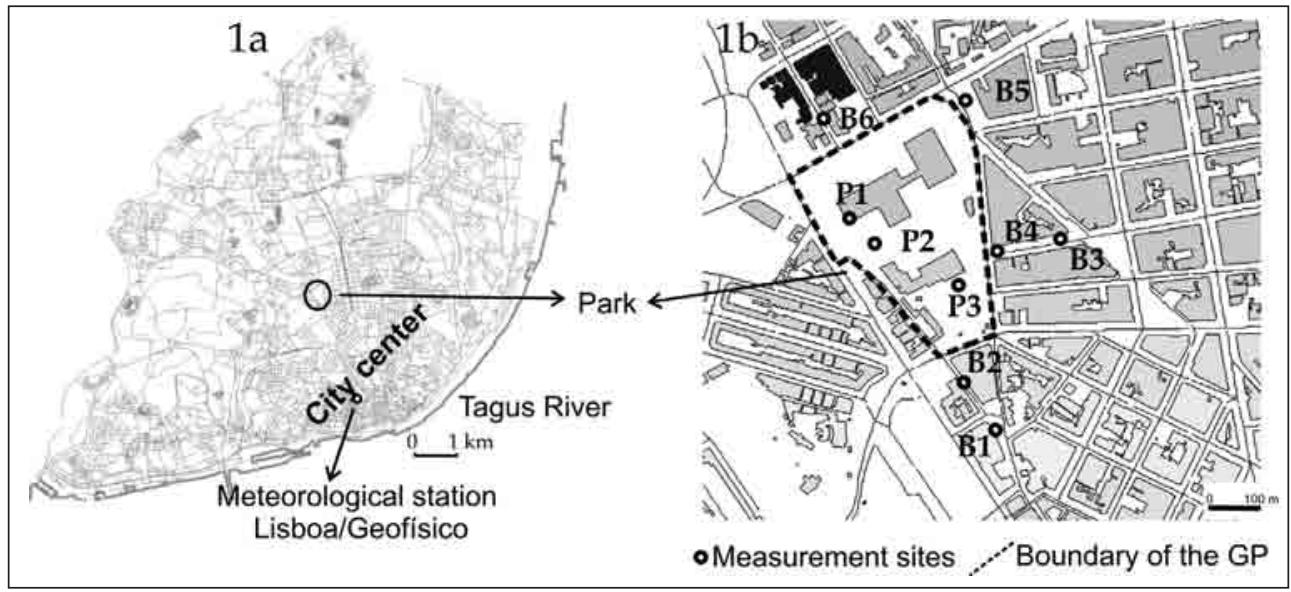

Fig.1 - Location of the GP in Lisbon (1a) and air temperature measurement network (1b) Fig. 1 - Localização do JG em Lisboa (la) e locais de medição da temperatura do ar (1b)

\section{The climatic functions of urban green spaces}

As with all other aspects that have an impact upon the urban climate, assessing the effects of vegetation requires an understanding of the influence of scale. To begin with, the effects brought on by the presence of individual plants differ from that those that are associated with large green areas (large urban parks and urban forest areas). Drawing on Oke (1987, 1989, 2004), Spronken-Smith and Oke (1998), Alcoforado (1996) and Andrade (2005), we have sought to synthesize the various climatic effects of green spaces in accordance with the climatic scale at which they occur (table I). In this classification, two different aspects were taken into account: on the one hand, the effects of the individual green spaces, regarded as "units of land use" - in this respect, their influence is largely a function of the area that they cover; on the other hand, the degree of climatic differentiation within each green space, as a function of features such as the type of vegetation, topography, etc.

As far as the climatic influence of green spaces is concerned, it is possible to identify a variety of effects, characterised by varying degrees of complexity, which occur at different scales:

- Influence of green spaces upon the radiation, energy, hydrological and momentum balances;

- Influence upon specific climatic features, such as the air temperature $(T a)$ and the wind speed (v);

- Combined influence of the climatic elements upon the energy balance of the human body, with consequences upon the level of thermal comfort and for human health. 


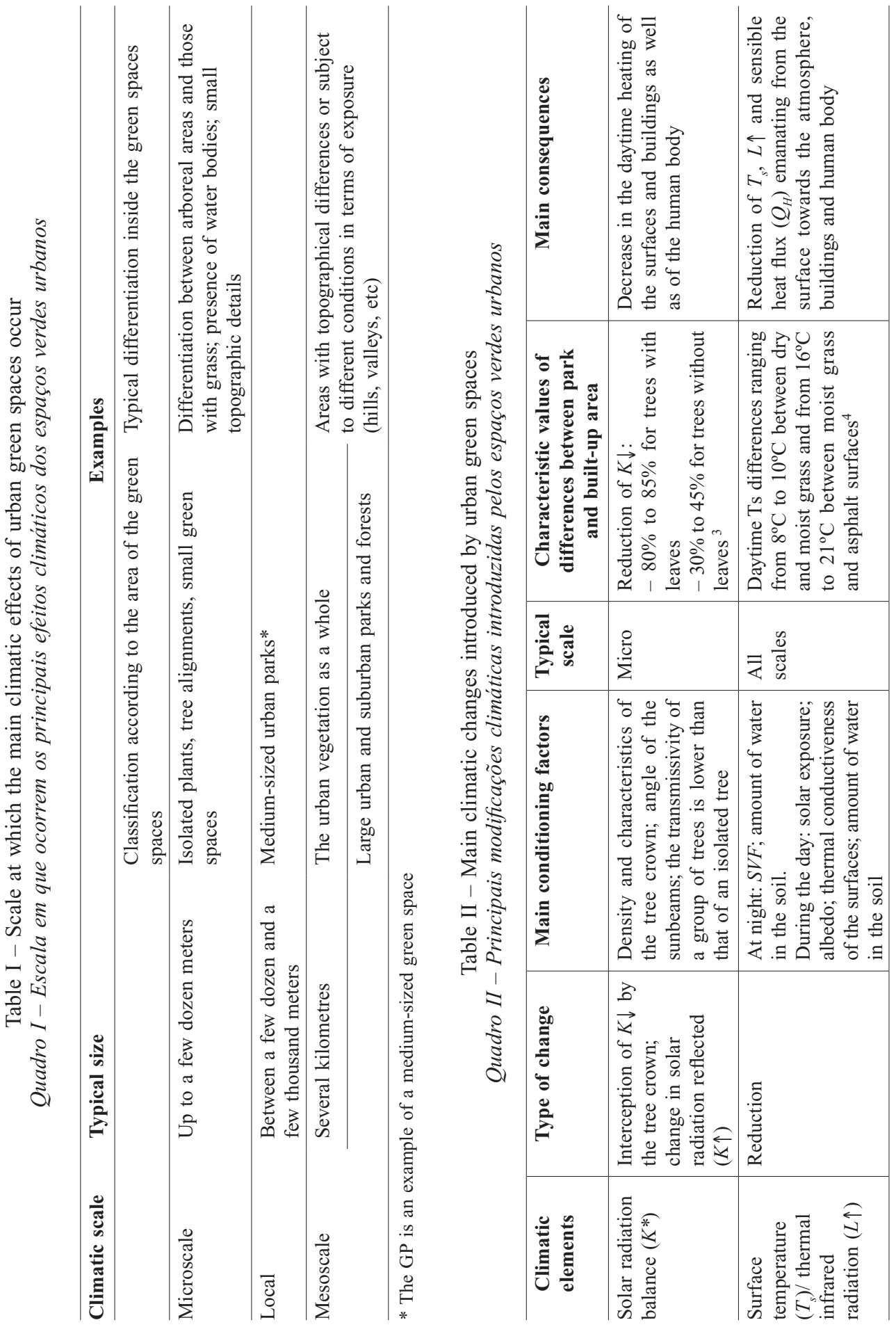




\begin{tabular}{|c|c|c|c|c|c|}
\hline 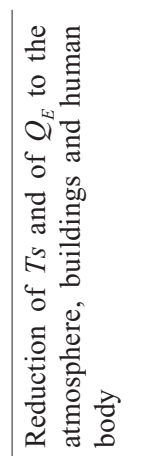 & 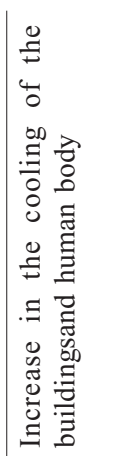 & 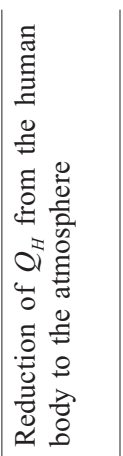 & 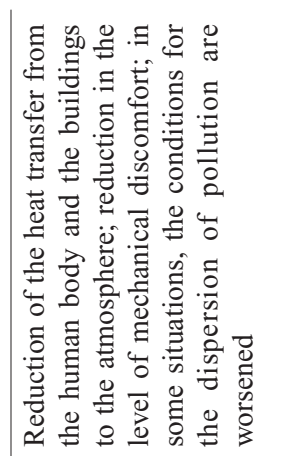 & 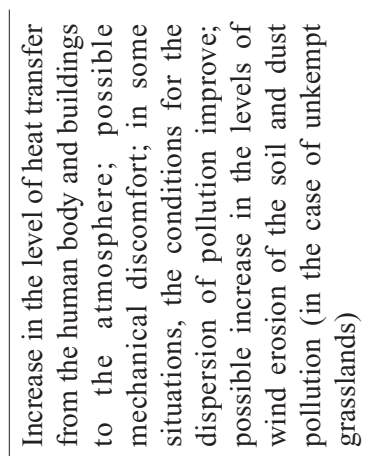 & \\
\hline 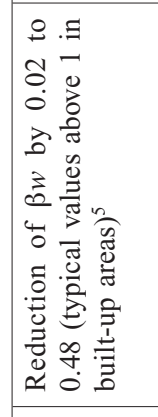 & 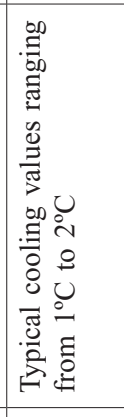 & 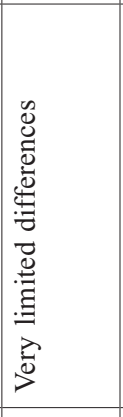 & 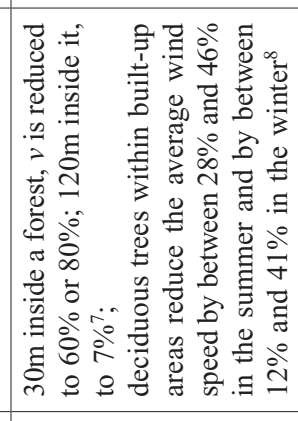 & 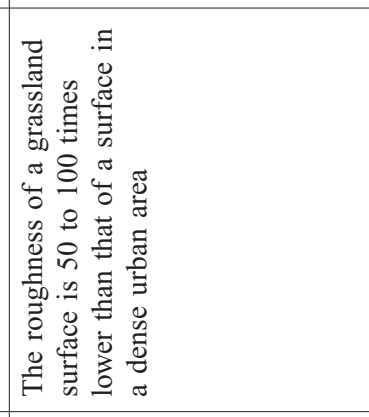 & \multirow{5}{*}{ 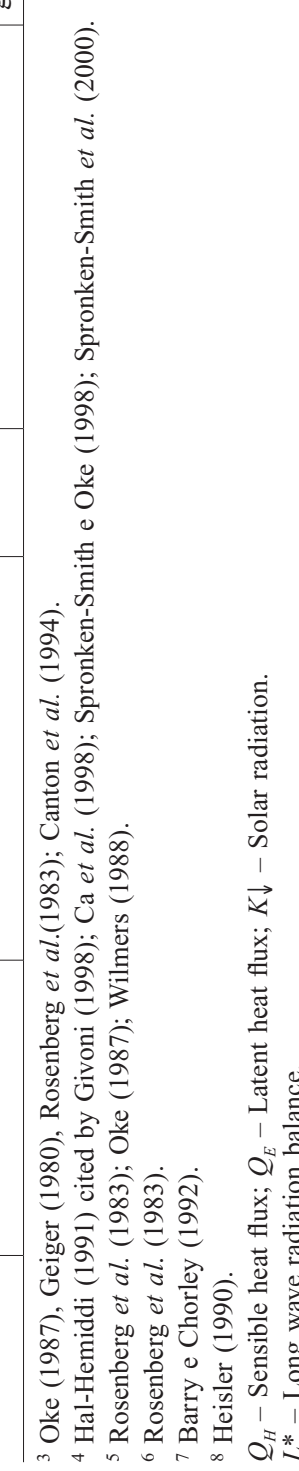 } \\
\hline $\bar{ষ}$ & 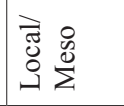 & 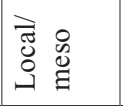 & 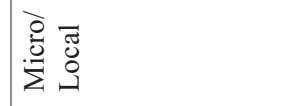 & 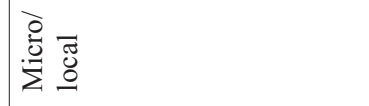 & \\
\hline 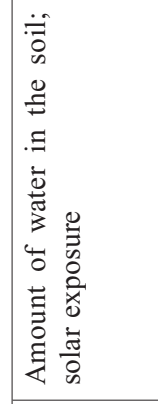 & 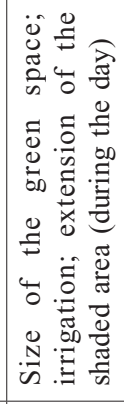 & 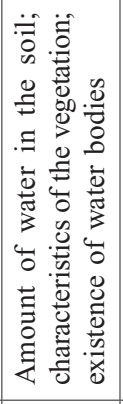 & 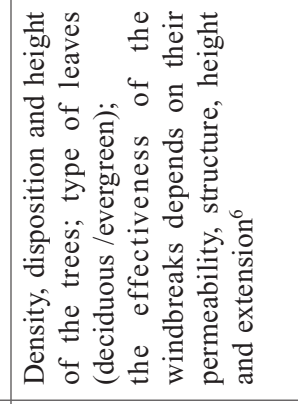 & 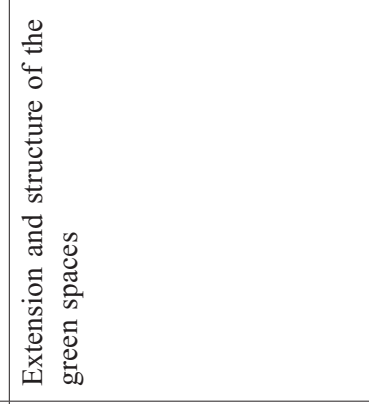 & \\
\hline 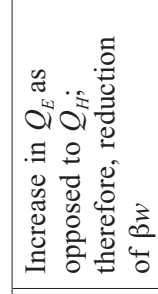 & & & 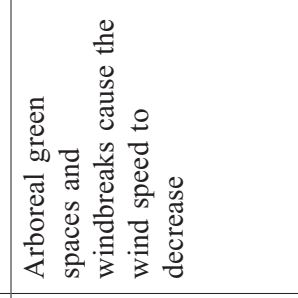 & 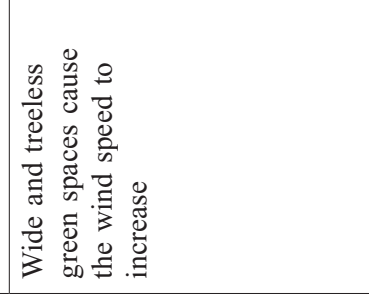 & \\
\hline 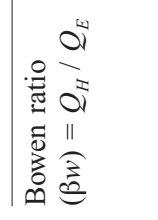 & 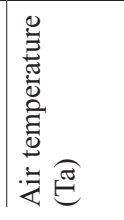 & 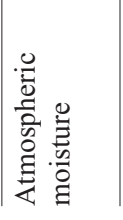 & & 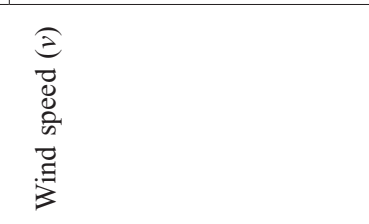 & \\
\hline
\end{tabular}


Alongside the aforementioned aspects, the influence of green spaces upon the levels of noise and air quality, which are important determinants of the quality of the urban atmosphere (Givoni, 1998; Beckett, et al.; 1998, Kuttler and Strassburger, 1999 and Upamnis, et al. 2001; Fang and Ling, 2003, 2005), are also commonly acknowledged. These latter aspects are not addressed in this paper.

Table II presents an attempt to synthesize the main climatic changes associated with urban green spaces.

The effects upon the wind conditions are complex: besides affecting the wind speed, we find that the larger green spaces that are characterised by pronounced thermal contrasts vis-à-vis the surrounding areas can, on stable nights, give rise to local advection (on the topic of breeze parks, see Oke, 1987 and 1989; Eliasson and Upmanis, 2000).

In sum, the main climatic changes brought about by green spaces consist of their cooling influence upon buildings, the atmosphere and the human body (even though the changes to the wind speed and the increase in the level of atmospheric moisture can have the opposite effect). For this reason, they play a particularly useful role in the summer, in urban areas and, above all, in a context of global heating. However, one should bear in mind the importance of avoiding simplistic, one-size-fits-all solutions that do not draw on an adequate understanding of the underlying mechanisms, since those solutions are often ill-suited to both the specific context and the intended objectives.

\section{MATERIALS AND METHODS}

\section{Local scale}

In this research, the GP was considered as a unit of land use, and, as such, differentiated with regard to the surrounding built-up area. We have sought to ascertain whether differences could be identified in terms of the thermal behaviour in the two areas.

In order to do this, fixed Ta sensors (table III) were placed in several different sites both inside and outside the park (fig. 1b; fig. 2; description of sites in table IV), during the periods indicated in table V. Measurements were undertaken throughout 117 summer days, 10 autumn days and 12 winter days. For this reason, the results for the summer period should be regarded as statistically more significant than those for the other seasons. In addition, the two summer periods during which the measurements were carried out included a wide variety of weather types, namely several rainy and cloudy days in August 2004 and some very hot days in July 2004 and August 2005 (the maximum temperatures recorded at Lisboa/Geofísico (fig. 1a) were $37.1^{\circ} \mathrm{C}$ on July $27^{\text {th }}, 2004$ and $38.2^{\circ} \mathrm{C}$ on August $4^{\text {th }}, 2005$ ).

$\mathrm{Ta}$ was recorded at 10-minute intervals, but the analysis of the data was based on their 30-minute average in order to enhance the consistency of the results. 
Table III - Measurement devices used for collecting data at the GP

Quadro III - Aparelhos de medição utilizados para recolha de dados no GP

\begin{tabular}{ll}
\hline Parameter & Device \\
\hline Air Temperature $(T a)$ & TinyTalk Sensor and data logger - Gemini Data Loggers \\
Relative humidity $(H R)$ & Rotronic A1 Termohygrometer \\
Wind speed $(v)$ & Kestrel 3000 Neilsen-Kellerman Anemometer \\
Solar radiation $(K)$ & $C M 21$ Kipp \& Zonen Pyranometer \\
Infrared radiation $(L)$ & $C G 1$ Kipp \& Zonen Pyrgeometer \\
\hline
\end{tabular}

Table IV - Characterization of the measurement sites

Quadro IV - Caracterização dos locais de medição

\begin{tabular}{|c|c|c|c|}
\hline Site & SVF $^{1}$ & $\begin{array}{l}\text { Period with direct solar } \\
\text { radiation } \\
\text { on August } 1^{\text {th }}\end{array}$ & Site Characteristics \\
\hline P1 & 0.79 & $7 \mathrm{am}-8 \mathrm{pm}$ & $\begin{array}{l}\text { Over the green terrace of a building, around } 6 \mathrm{~m} \\
\text { above the topographical surface }\end{array}$ \\
\hline P2 & 0.16 & - & Under dense tree cover \\
\hline $\mathrm{P} 3$ & 0.49 & $6 a m-10 a m ; 16 a m-19 a m$ & Average tree density \\
\hline B1 & 0.60 & $6 a m-13 p m$ & Small urban square; site exposed to the East \\
\hline B2 & 0.53 & $6.30 \mathrm{am}-13 \mathrm{pm}$ & NW-SE street; site exposed to the East \\
\hline B3 & 0.29 & $7.30 \mathrm{am}-14 \mathrm{pm}$ & E-W street with trees; site exposed to the South \\
\hline B4 & 0.61 & $7 \mathrm{am}-19 \mathrm{pm}$ & Street corner \\
\hline B5 & 0.75 & $8 \mathrm{am}-8 \mathrm{pm}$ & Open area near the GP boundary \\
\hline B6 & 0.48 & 7.30am $-2 \mathrm{pm}$ & NW-SE street; site exposed to the East \\
\hline
\end{tabular}

1 SVF $=$ Sky View Factor

Table V - Measurement periods of Ta

Quadro V-Períodos de medição da Ta

\begin{tabular}{ll}
\hline Summer & June $23^{\text {rd }}-$ September $12^{\text {th }}, 2004$ \\
& July $25^{\text {th }}-$ August $29^{\text {th }}, 2005$ \\
Autumn & September $28^{\text {th }}-$ October $7^{\text {th }}, 2004$ \\
Winter & January $12^{\text {th }}-24^{\text {th }}, 2005$ \\
\hline
\end{tabular}



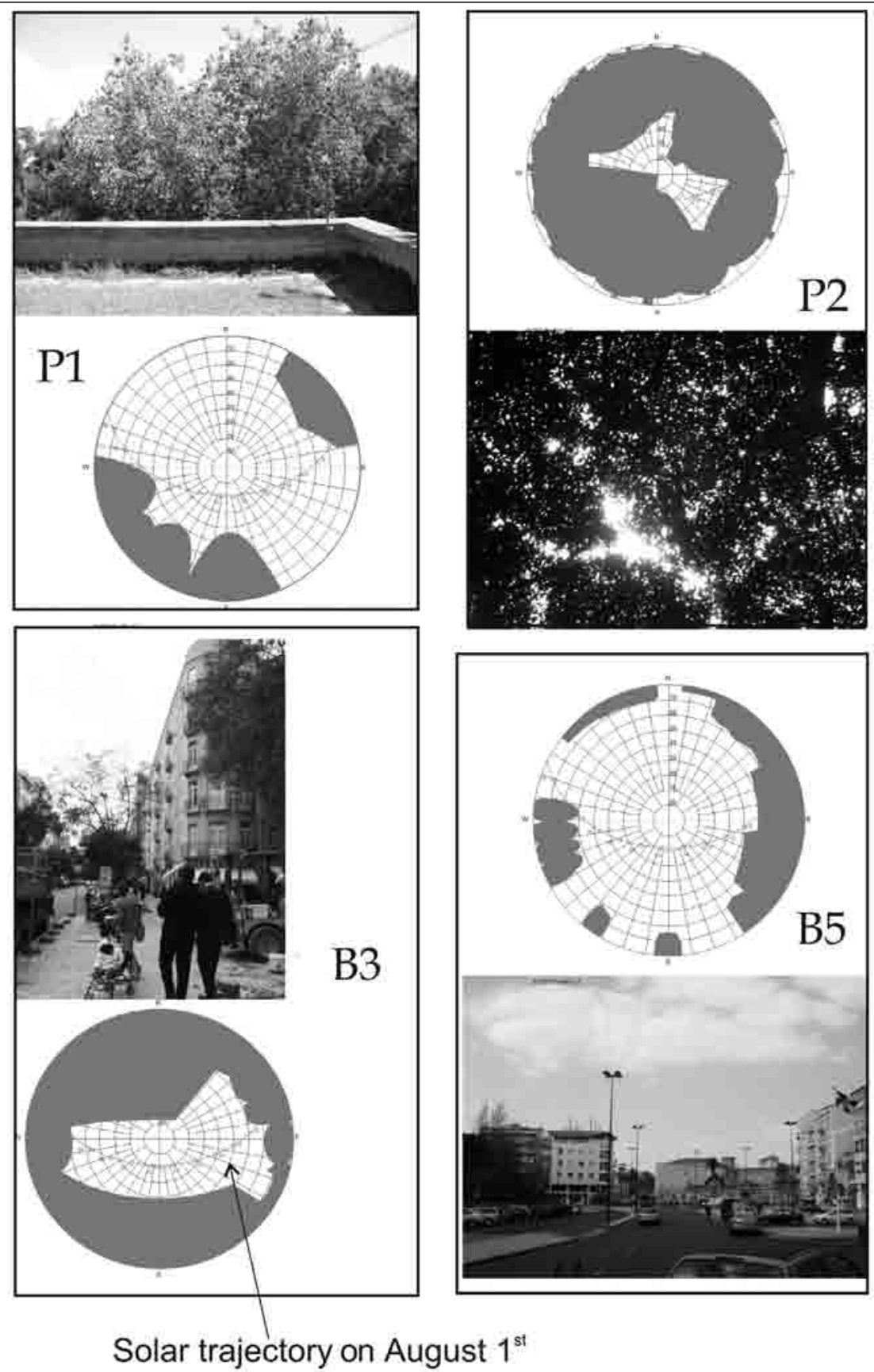

Fig. 2 - Solar diagrams and photographs of some of the measurement sites Fig. 2 -Diagramas solares e fotografias dos locais de medição 


\section{Microscale}

The second part of the study was based on itinerant measurements of $T a, H R$, $v, K$ and $L$ in ten different sites located within the park. The measurements were undertaken in the summers of 2004 and 2005, during the daytime - the time when the Park is subject to greatest use. We have sought to assess not only the variation in the measured climatic features, but also the combined influence of those elements upon the human body, in accordance with the concept of Physiological Equivalent Temperature (PET - Mayer and Höppe, 1987; Höppe, 1993, 1999; Matzarakis, Mayer and Iziomon, 1999). This enabled us to reach a number of conclusions with regard to the level of thermal comfort of the park's users. A discussion of the problems associated with the use of the PET in the context of Lisbon's climate can be found in Andrade and Alcoforado (in press).

\section{RESULTS}

\section{Local scale}

The daytime and nighttime periods were analysed separately. Many studies of the thermal behaviour of green spaces have focused exclusively on the nighttime period, since it is at this latter time that the urban heat island phenomenon is at its highest (Oke, 1987; Alcoforado, 1992; Alcoforado and Andrade, 2006). However, from the point of view of the users of green spaces, the daytime period is clearly more important.

\subsection{Daytime period}

The analysis of the daytime conditions refers to the following periods. In the summer between 9am and 6.30pm; in the autumn between 9am and 6pm; in the winter between $10 \mathrm{am}$ and $5 \mathrm{pm}$.

Table VI summarises the main thermal effects associated with the presence of the park. In order to compare the park with the surrounding built-up area, the following parameter was used:

$$
\Delta \operatorname{med}_{\mathrm{t}}=\operatorname{med}_{\mathrm{ut}}-\operatorname{med}_{\mathrm{vt}}
$$

where:

$\Delta \operatorname{med}_{\mathrm{t}}=$ difference between the medians of $T a$, at time $\mathrm{t}$ $\operatorname{med}_{\mathrm{ut}}=$ median of $T a$ in the surrounding built-up area at time $\mathrm{t}$ $\operatorname{med}_{\mathrm{vt}}=$ median of $T a$ in the Park at time $\mathrm{t}$.

This parameter reflects the overall thermal behaviour of the green space as compared to the surrounding built-up area, while controlling for the specificities of the various different measurement sites. The use of the median enabled us to 
circumvent the effect of the extreme values of $T a$, as well as that of missing data due to technical problems - both of which usually affect the mean more than they affect the median.

On the other hand, the parameter consisting of the maximum spatial differences between the park and the surrounding built-up area at any given moment ("park cool island" - Spronken-Smith and Oke, 1998) can also be used to characterise the thermal influence of the green space:

$\Delta \max _{\mathrm{t}}=\operatorname{Tmax}_{\mathrm{ut}}-\operatorname{Tmin}_{\mathrm{vt}}$

where:

$\Delta \max _{\mathrm{t}}=$ maximum difference at time $\mathrm{t}$

$\operatorname{Tmax}_{\mathrm{ut}}=$ highest Ta in the built-up area at time $\mathrm{t}$

$\operatorname{Tmin}_{\mathrm{vt}}=$ lower Ta in the park area at time $\mathrm{t}$.

Two series of values were thus produced, for $\Delta \operatorname{med}_{\mathrm{t}}$ and $\Delta \max _{\mathrm{t}}$ respectively. The statistical characterization of these two series is presented in table VI.

Table VI - Statistical characterization of the differences in Ta between the park and the surrounding built-up area in the daytime period

Quadro VI - Caracterização estatística das diferenças de Ta entre o Jardim e a área construída envolvente no período diurno

\begin{tabular}{|c|c|c|c|c|c|c|c|c|c|c|c|c|c|c|}
\hline & & & & $\Delta \mathbf{m}$ & & & & & & & $\Delta \mathrm{m}$ & & & \\
\hline & & & & ercent & les $\left({ }^{\circ} \mathrm{C}\right.$ & & & & & & rcenti & es $\left({ }^{\circ} \mathrm{C}\right.$ & & \\
\hline & n & $\begin{array}{c}\text { Mini- } \\
\text { mun } \\
\left({ }^{\circ} \mathrm{C}\right)\end{array}$ & $15^{\text {th }}$ & $50^{\text {th }}$ & $85^{\text {th }}$ & $\begin{array}{c}\text { Maxi- } \\
\text { mum } \\
\left({ }^{\circ} \mathrm{C}\right)\end{array}$ & $\%>0$ & n & $\begin{array}{l}\text { Mini- } \\
\text { mum } \\
\left({ }^{\circ} \mathrm{C}\right)\end{array}$ & $15^{\text {th }}$ & $50^{\text {th }}$ & $85^{\text {th }}$ & $\begin{array}{c}\text { Maxi- } \\
\text { mum } \\
\left({ }^{\circ} \mathrm{C}\right)\end{array}$ & $\%>0$ \\
\hline Summer & 1809 & -3.5 & 0 & 1.3 & 2.9 & 5.4 & 83 & 1630 & -3.2 & 2.2 & 4.1 & 5.8 & 9.5 & 100 \\
\hline Autumn & 218 & -0.1 & 0.9 & 1.8 & 2.7 & 4.6 & 100 & 218 & 0.8 & 2.4 & 4.1 & 5.5 & 7.5 & 100 \\
\hline Winter & 117 & -1.6 & -0.7 & 0.12 & 0.49 & 0.9 & 56 & 117 & 0.2 & 0.7 & 1.4 & 2.3 & 3.7 & 100 \\
\hline
\end{tabular}

In the summer, the daytime median temperature in the Park was lower than that in the surrounding built-up area in $83 \%$ of the cases: the median difference exceeded $1.3^{\circ} \mathrm{C}$ in $50 \%$ of the cases and $2.9^{\circ} \mathrm{C}$ in $15 \%$. The effect in terms of thermal differentiation during the autumn was similar to that in the summer, which was due to the fact that the short autumn data-collection period was characterised by anticyclonic conditions and high temperatures. In the winter, the median differentiation was much less significant, and the thermal conditions in the green space could hardly be distinguished from those in the surrounding area.

Turning our attention to $\Delta \max _{t}$, we find that, in almost $100 \%$ of the observations and regardless of the time of the year, the measurement sites located outside the green space were hotter than those inside it. The largest differences, reaching as much as $9.5^{\circ} \mathrm{C}$, occurred in the summer. 
The situations in which the thermal impact of this green space was most significant consisted of very hot days (with temperatures nearing $40^{\circ} \mathrm{C}$ ) characterised by clear sky and weak wind from the NE (typical conditions for the occurrence of heat waves in Lisbon). As might be expected, under these conditions the lowest temperatures $\left(30^{\circ} \mathrm{C}\right.$ to $\left.33^{\circ} \mathrm{C}\right)$ were recorded in those parts of the park that were under dense shade. The values of Ta in the P1 site, which is located inside the park and is subject to many daily hours of solar exposure (fig. 2), were very similar to those recorded in the surrounding built-up area.

The thermal differences between the measurement sites are strongly associated with their degree of exposure to direct solar radiation. Sites in the shade and sites under the sun were selected both inside and outside the park, and those sites that were located under the sun inside the green space tended to be hotter than those that were located in the built-up area but in the shade. With the aim of ascertaining the influence of the green space upon the Ta while controlling for the degree of exposure to the sun, a comparison was made between sites characterised by similar exposure conditions in the two areas (inside and outside the park).

Figure 3 provides a clear indication of the influence of the green space upon the temperature of the sites in the shade inside the park, as compared to those located outside the park (table IV). Site $\mathrm{P} 2$ was around $5.0^{\circ} \mathrm{C}$ cooler than site $\mathrm{B} 3$ during most of the afternoon period, and $0.9^{\circ} \mathrm{C}-1.6^{\circ} \mathrm{C}$ cooler than site $\mathrm{B} 6$ (which was the second coolest).

If we instead examine the values for the sites under the sun, we find that those located inside the Park were clearly cooler, particularly in the afternoon period (fig. 4): the differences were especially significant after $4 \mathrm{pm}$. The temperature figures were highest in the B4 site, which is located outside the park and close to a wall facing west: the median difference compared to the $\mathrm{P} 1$ site was $2.2^{\circ} \mathrm{C}$ at $5 \mathrm{pm}$. In the morning period (fig. 4), the temperatures in the P1 and B5 sites were very similar: the values of the Ta recorded in the two sites cannot be statistically distinguished. The sites furthest away from the Park (B1 and B6) tended to be the hottest: their proximity to walls facing south contributes to the high temperatures recorded in these sites.

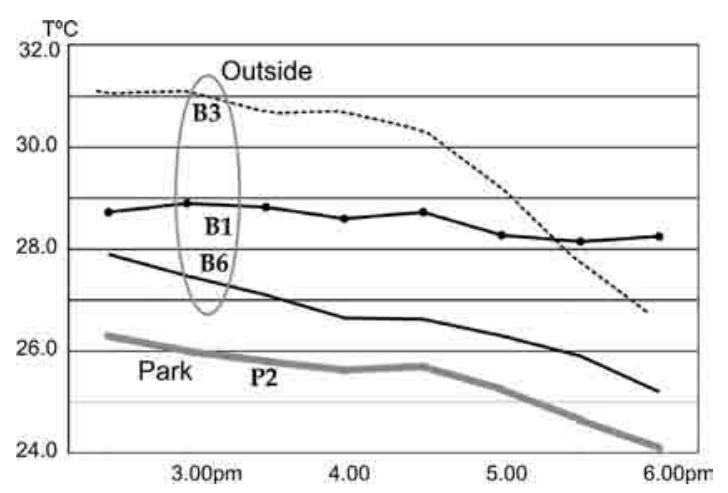

Fig. 3 - Median air temperature in sites in the shade, during summer afternoons Fig. 3 - Temperatura mediana do ar nos locais à sombra, durante as tardes de verão 


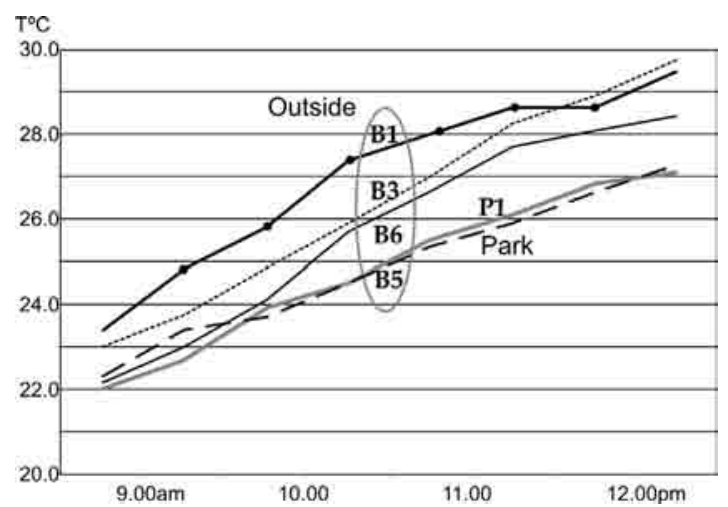

Fig. 4 - Median air temperature in sites under the sun, during summer mornings Fig. 4 - Temperatura mediana do ar nos locais ao Sol, durante as manhãs de Verão

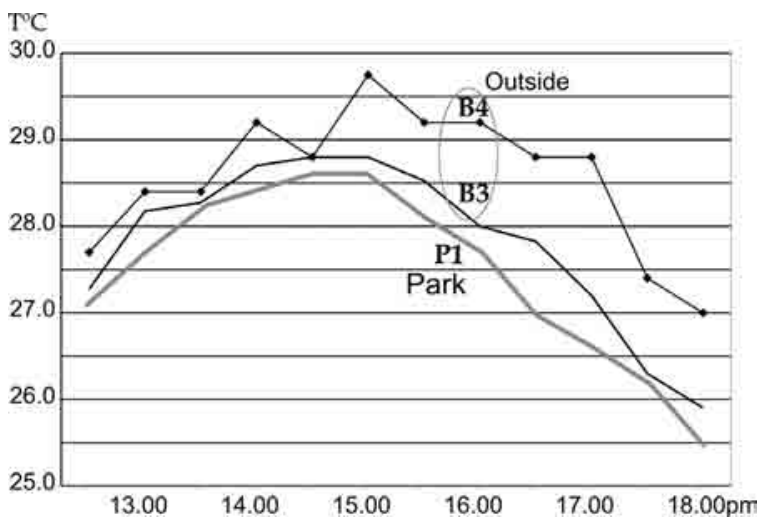

Fig. 5 - Median air temperature in sites under the sun, during summer afternoons Fig. 5 - Temperatura mediana do ar nos locais ao Sol, durante as tardes de Verão

\subsection{Nighttime period}

The following periods were considered in the analysis of the nighttime conditions: in the summer and autumn, between $11 \mathrm{pm}$ and 5am; in the winter, between $9 \mathrm{pm}$ and $7 \mathrm{am}$. The statistical analysis of the differences between the measurement sites (table VII) was similar to that for the daytime period. In terms of the $\Delta \operatorname{med}_{t}$ parameter, we find that the park was almost always cooler than the surrounding built-up area, even though the differences were relatively small: in the summer, the difference exceeded $1{ }^{\circ} \mathrm{C}$ in only $15 \%$ of the cases. Naturally, the $\Delta \max _{\mathrm{t}}$ parameter was higher: in the summer periods, it exceeded $1.4^{\circ} \mathrm{C}$ in $50 \%$ of the cases and $2.5^{\circ} \mathrm{C}$ in $15 \%$ of the cases. 
Table VII - Statistical characterisation of the differences in Ta between the park and the surrounding built area in the nighttime period

Quadro VII - Caracterização estatística das diferenças entre o Jardim e a área construída envolvente, no periodo nocturno

\begin{tabular}{|c|c|c|c|c|c|c|c|c|c|c|c|c|c|c|}
\hline & \multicolumn{7}{|c|}{$\Delta$ med $_{\mathrm{t}}$} & \multicolumn{7}{|c|}{$\Delta \max _{t}$} \\
\hline & \multicolumn{7}{|c|}{ Percentiles $\left({ }^{\circ} \mathrm{C}\right)$} & \multicolumn{7}{|c|}{ Percentiles $\left({ }^{\circ} \mathrm{C}\right)$} \\
\hline & $\mathbf{n}$ & $\begin{array}{l}\text { Mini- } \\
\text { mun } \\
\left({ }^{\circ} \mathrm{C}\right)\end{array}$ & $15^{\text {th }}$ & $50^{\text {th }}$ & $85^{\text {th }}$ & $\begin{array}{c}\text { Maxi- } \\
\text { mum } \\
\left({ }^{\circ} \mathrm{C}\right)\end{array}$ & $\%>0$ & $\mathbf{n}$ & $\begin{array}{l}\text { Mini- } \\
\text { mum } \\
\left({ }^{\circ} \mathrm{C}\right)\end{array}$ & $15^{\text {th }}$ & $50^{\text {th }}$ & $85^{\text {th }}$ & $\begin{array}{l}\text { Maxi- } \\
\text { mum } \\
\left({ }^{\circ} \mathrm{C}\right)\end{array}$ & $\%>0$ \\
\hline Summer & 555 & -0.3 & 0.3 & 0.7 & 1.0 & 2.0 & 96 & 487 & 0.5 & 0.9 & 1.4 & 2.5 & 4.1 & 100 \\
\hline Autumn & 70 & 0.34 & 0.5 & 0.8 & 1.6 & 2.1 & 100 & 70 & 0.77 & 0.88 & 1.36 & 2.67 & 3.3 & 100 \\
\hline Winter & 130 & -0.1 & 0.1 & 0.4 & 1.4 & 1.77 & 95 & 130 & 0 & 0.3 & 0.74 & 2.34 & 3.9 & 98 \\
\hline
\end{tabular}

Four different sites, representing four different micro-environments, were compared: sites P1 and P2 inside the Park (table IV, fig. 2) and sites B3 and B5 outside the Park.

The median temperature was computed for every hour of the nighttime period (fig. 6). The two sites located outside the Park experienced temperatures above those recorded inside the green space: the median difference between site $\mathrm{B} 3$ and the Park was $0.9^{\circ} \mathrm{C}$, and between site B5 and the Park, $0.5^{\circ} \mathrm{C}$. The difference between sites B3 and B5 was found to be a consequence of the difference between the two sites' $S V F$ (0.75 in site B5; 0.29 in site B3), and, consequently, of the differences in radiation balance between the two sites. The fact that site B3 is further away from the Park and sheltered from the wind may also have contributed to the thermal difference. Site P2, located inside the Park and under dense tree cover (fig. 2 ; SVF $=0.16)$, was cooler than site B5 $(\mathrm{SVF}=0.76)$ in $83 \%$ of the cases, with a median difference of $-0.5^{\circ} \mathrm{C}$. The difference between the two sites was found to be statistically significant $(F=27.3$, for a critical value of 3.8 at a level of significance of 0.95 ). The previous figures refer to the summer period; in the winter, the difference between the two sites was not found to be statistically significant $(\mathrm{F}=0.31$, for a critical value of 3.8 at a level of significance of 0.95 ). This means that in the summer considerable evaporative cooling takes place inside the green space (even during the night), which causes the site inside the park to be cooler despite its lower SVF; in the winter, by contrast, the effect of the SVF is relatively more important, especially in those nights in which there is radiative cooling: in 10\% of the coolest periods, site B5 was cooler than site P2, but warmer than site P1 (which has a SVF of 0.79). 


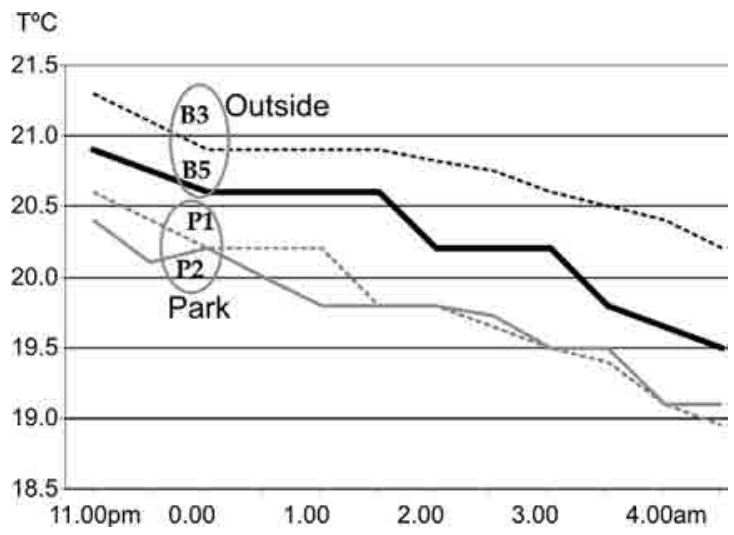

Fig. 6 - Median air temperature during summer nights

Fig. 6 - Temperatura mediana do ar, durante as noites de verão

Overall, there was virtually no difference in the Ta between sites P1 and P2; thus, this parameter did not reflect the difference between these two sites in terms of $S V F$ (table IV). The difference between the series for the two sites was not statistically significant $(F=0.21$, for a critical value of 3.8 at a level of significance of 0.95 ); however, if we consider only the five coolest nights (in which there was intense radiative cooling) in the summer and the winter (fig. 7), we find that the P1 site was almost always cooler, even though in the summer this difference only became significant after $11.30 \mathrm{pm}$ (and increased throughout the night).

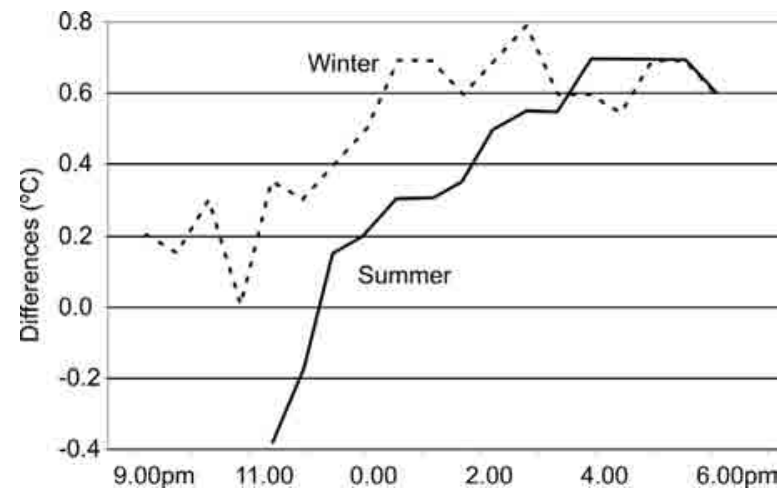

Fig 7 - Median differences between sites P1 (open) and P2 (dense tree cover), in the 5 coolest nights of each season

Fig. 7 - Mediana das diferenças entre os locais P1 (aberto) e P2 (cobertura arbórea densa), nas 5 noites mais frias de cada estação do ano 


\section{Microclimatic study}

Clearly, the main factor behind microclimatic differentiation is the degree of exposure to direct solar radiation $(K \downarrow)$. Figure 8 presents a synthesis of the differences between the measurements undertaken in sites located in the shade and in those located under the sun. As might be expected, the greatest differences found between the sites in the shade and those under the sun are in terms of global K (an average $88 \%$ reduction of $\mathrm{K} \downarrow$ in the sites in the shade, with values ranging between $97 \%$ and $70 \%$ ), even though the sites in the shade are also characterised by higher levels of $\mathrm{L} \downarrow$ (and of the infrared balance $L^{*}$ ). The overall result is a much higher radiation balance $\left(Q^{*}\right)$ and higher $\mathrm{T}_{\text {mrt }}$ in the sites exposed to direct solar radiation. The average difference in the $\mathrm{Ta}$ is much lower (a mere $4.0^{\circ} \mathrm{C}$ ); however, the difference in the PET exceeds $18^{\circ} \mathrm{C}$.

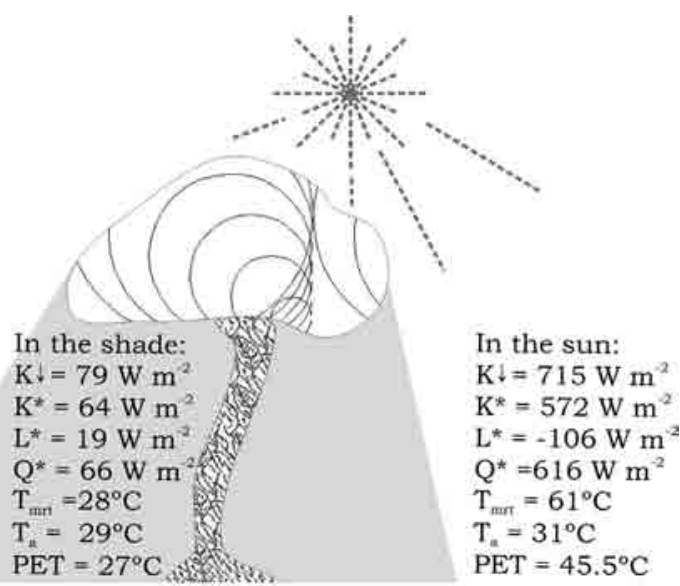

Fig. 8 - Median of the results of the measurements made in the sun and in the shade Fig. 8 - Mediana dos resultados das medições à sombra e ao Sol

The reduction in $\mathrm{K} \downarrow$ and $\mathrm{T}_{\text {mrt }}$ was much more significant in those sites that are located under groups of trees than in those located under isolated trees: in the case of the site represented in figure 9a, the average reduction in $K \downarrow$ was $94 \%$ and the $\mathrm{T}_{\text {mrt }}$ was $26^{\circ} \mathrm{C}$, whereas in the site depicted in fig. $9 \mathrm{~b}$, the average reduction in $K \downarrow$ was $76 \%$ and the $\mathrm{T}_{\text {mrt }}$ was $33^{\circ} \mathrm{C}$. These differences are largely due to the lateral fluxes of diffuse $K$ : under isolated trees, $K \downarrow$ was 4.1 times higher than under groups of trees, but the lateral fluxes were 9 times as high. 

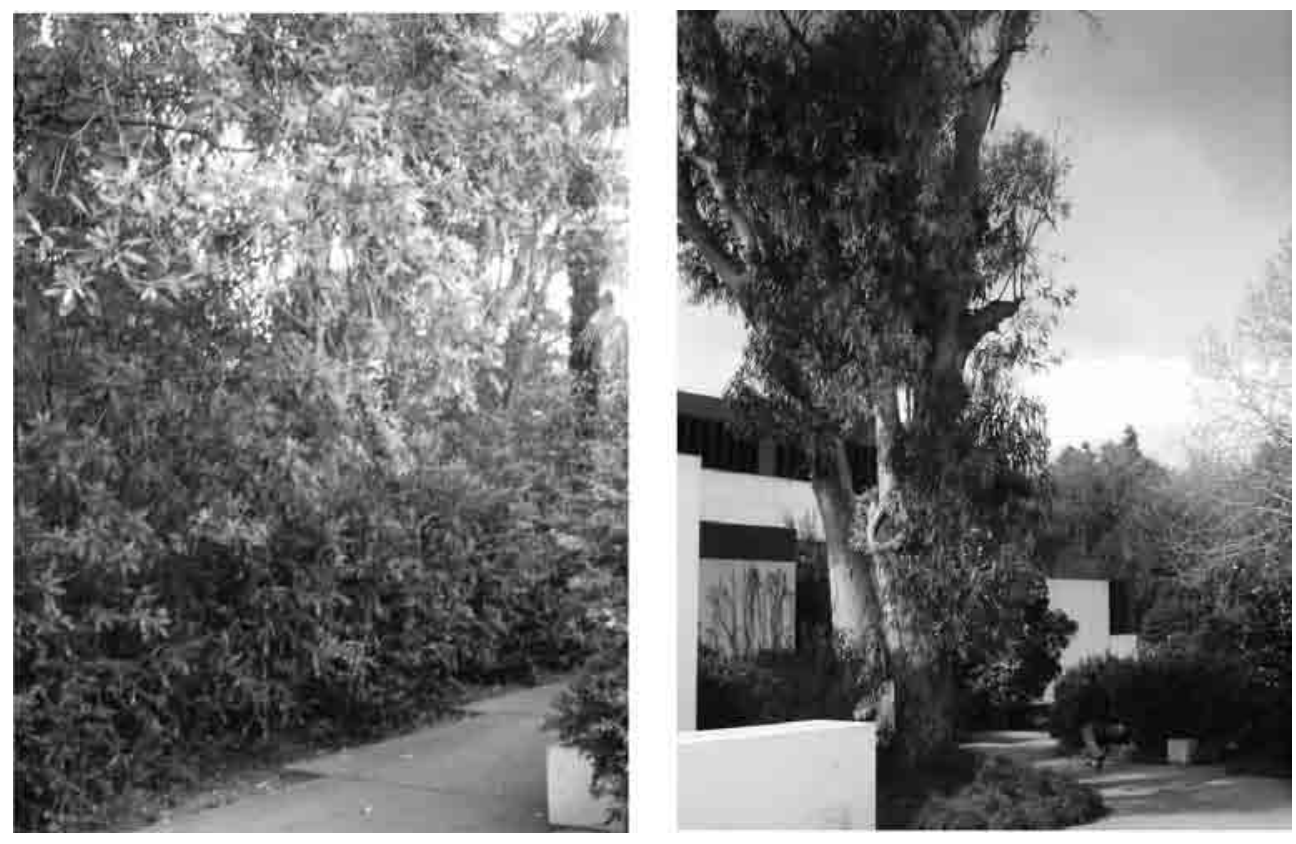

Fig. 9. Measurement sites of solar radiation:

9a. under a dense tree cover; 9b. under an isolated tree

Fig. 9 - Locais de medição da radiação solar:

9a. sob cobertura arbórea densa; 9b. sob uma árvore isolada

These radiation measurements were carried out when the trees were totally covered with leaves. Naturally, the results in the colder part of the year can be very different in the case of deciduous trees. Radiation measurements undertaken in the same Park in the winter of 1998 showed that under a cover of deciduous trees, the reduction in $K \downarrow$ varied between $95 \%$ and $56 \%$ throughout the winter. This variation was attributed to two factors: the decrease in the level of tree cover as the winter progressed, and the increase in the height of the sun, allowing for greater sunbeam penetration. These results are consistent with the conclusion that (contrary to what is commonly considered) deciduous trees can constitute a significant barrier to solar radiation even in the winter (Rosenberg, et al., 1983; Oke, 1989; Canton, et al., 1994), and especially so in climates characterised by mild winters (Canton, et al., 1994).

\section{DISCUSSION AND CONCLUSION}

The conclusions to be drawn from this study concern, on the one hand, the local differentiation between the Park and the surrounding built-up area, and, on 
the other, the microclimatic differentiation within the Park itself. This green space was cooler than the surrounding built-up area in all seasons, but especially so during the summer. In this latter season, during the daytime, the median difference amounted to $1.3^{\circ} \mathrm{C}$ and the maximum difference exceeded $4.1^{\circ} \mathrm{C}$ in $50 \%$ of the cases. The park was particularly cool (in relative terms) under very hot weather conditions (mean local temperature above $35^{\circ} \mathrm{C}$ ), when the extreme difference exceeded $9^{\circ} \mathrm{C}$. These observations support the conclusion that green spaces play an important role in mitigating situations of extreme heat.

The aforementioned differences did not control for the differences in terms of solar exposure; sites in the shade and sites under the sun were selected both inside and outside the GP, and it goes without saying that, during the summer, the sites under the sun were always hotter, regardless of their location. However, it was found that, under similar solar exposure conditions (sun/shade), the sites inside the GP were almost always cooler than those located outside the park: the difference between the sites under the sun located inside and outside the park reached $2^{\circ} \mathrm{C}$ to $3^{\circ} \mathrm{C}$; in the case of the sites in the shade, the difference was as high as $5^{\circ} \mathrm{C}$.

During the nighttime period, the park was also almost always cooler than the surrounding built-up area, but the differences were less significant: the median difference in the summer amounted to $0.7^{\circ} \mathrm{C}$, and extreme differences above $1.4^{\circ} \mathrm{C}$ were found in $50 \%$ of the cases. Within the Park, there was little thermal differentiation during the nighttime period, but in nights characterised by intense radiative cooling, open spaces were found to have a considerable cooling effect.

According to several authors, the size of green spaces is an important determinant of their thermal differentiation effect, and should accordingly be taken into account by urban planners. The significant thermal effect of large parks has been abundantly demonstrated (Jauregui, 1990/91; Barradas, 1991; SpronkenSmith and Oke, 1998; Upmanis, et al, 1998; Yu and Hien, 2006). The GP, which covers an area of 8.5 ha and can therefore be considered a medium-sized green area, has a clearly significant thermal impact, even though its thermal influence upon the surrounding built-up area could not be proven beyond doubt (it is probably rather insignificant). The thermal impact of small green areas is more doubtful, even though Saito et al. (1990/91), for example, found significant cooling occurring in a park of only 0.4 ha. Previous measurements carried out in Lisbon produced similar results (Alcoforado, 1996); not only are some exogenous factors (such as the specific measurement techniques used, the weather types and the size of the samples) likely to influence the results, it also seems impossible to establish a linear relationship between the size of the parks and the thermal differentiation associated with them, due to the fact that the latter is highly dependent upon the structure of the vegetation, the topography and the characteristics of the built-up area. Still, it is worth pointing out that even though small green spaces may not have a significant thermal influence, they do perform other microclimatic (as well as biophysical and social) functions, such as reduc- 
ing the solar radiation at the surface level (Hoyano, 1988; Oke, 1989; Matzarakis and Mayer, 1998; Barradas, 2000).

The main microclimatic differences within the Park itself during the daytime concerned the levels of solar radiation and Tmrt: $\mathrm{K} \downarrow$ in the shade was on average $12 \%$ that recorded in the sites under the sun, and $\mathrm{T}_{\text {mrt }}$ was $33^{\circ} \mathrm{C}$ lower; the average difference in Ta was only $2^{\circ} \mathrm{C}$. The reduction in the level of solar radiation under groups of trees was also significant. These results clearly demonstrate the importance of shade in the summer, although one should bear in mind that, in the winter, shades do not have a positive climatic effect. All these conclusions provide evidence to support the importance of ensuring, and adequately planning for, the microclimatic diversity of green spaces.

\section{AKNOWLEDGMENTS}

This research was partly funded by the Lisbon City Council and has been continued in the framework of the project UrbKlim (POCI/GEO/61148/2004) financed by FCT (Portugal) and by the Operational Programe for Science and Innovation 2010. The authors wish to thank Fundação Calouste Gulbenkian for the assistance provided while undertaking the research and for the financing the equipment necessary to carry out the radiation measurements, Prof. Maria João Alcoforado for reading and giving useful comments on this article, Dra. Sandra Oliveira for the help in translating and revising it, as well as the two anonymous reviewers for their helpful comments.

\section{REFERENCES}

Alcoforado M J (1996) Comparaison des ambiances bioclimatiques estivales d'espaces verts de Lisbonne. Publications de l'Association Internationale de Climatologie, 9: 273-280.

Alcoforado M J, Andrade H (2006) Nocturnal urban heat island in Lisbon Portugal: main features and modelling attempts. Theor. Appl. Climatol., 84 (1-3): 151-159.

Andrade H (2005) Clima urbano. Natureza, escalas de análise e aplicabilidade. Finisterra - Revista Portuguesa de Geografia, XL (80): 67-91.

Andrade H, Alcoforado M J (2007) Microclimatic variation of thermal comfort in a district of Lisbon Telheiras at night. Theor. Appl. Climatol. (DOI 10.1007/s00704-007-0321-5)

Barradas V L (2000) Energy balance and transpiration in an urban tree hedgerow in Mexico City. Urban Ecosystems, 4:55-67.

Barradas V L (1991) Air temperature and humidity and human comfort index of some city parks of Mexico City. Int. J. of Biometeorol., 35: 24-28.

Barry R G, Chorley R J (1992) Atmosphere, Weather and Climate. Routledge, London.

Baycan-Levent T, Leeuwen E V, Rodenburg C, Nijkamp P (2002) Development and management of green spaces in European cities: a comparative analysis. In: Research Memoranda, 25, Free University Amsterdam, Faculty of Economics, Business Administrtion and Econometrics. 
Beckett K P, Freer-Smith P H, Taylor G (1998) Urban woodlands: their role in reducing the effects of particulate pollution. Environmental Pollution, 993: 347-360.

Ca V T, Asaeda T, Abu E M (1998) Reductions in air conditioning energy caused by a nearby park. Energy Buildings, 29: 83-92.

Canton M A, Cortegoso J L, Rosa C (1994) Solar permeability of urban trees in cities of western Argentina. Energy Buildings, 20: 219-230.

Eliasson I, Upmanis H (2000) Nocturnal outflow from urban parks - implications for the city ventilation. Theor. Appl. Climatol., 66: 95-107.

Geiger R, Aron R, et al. (1995) The climate near the ground. Wiesbaden, Friedr. Vieweg \& Sohn.

Fang C F, Ling D L (2005) Guidance for noise reduction provided by tree belts. Landscape and urban planning, 71: 29-34.

Fang C F, Ling D L (2003) Investigation of the noise reduction provided by tree belts. Guidance for noise reduction provided by tree belts. Landscape and urban planning, 66: 187-195.

Greater London Autority (2001) The benefits of green space. In: Scrutiny of Green Spaces in London. Greater London Authority, London.

Givoni B (1998) Climate considerations in building and urban design. John Wiley \& Sons, Inc, New York.

Heisler G M (1990) Mean wind speed below building height in residential neighborhoods with different tree densities. Ashrae Transaction, 96(1): 1389-1396.

Hoyano A (1988) Climatological uses of plants for solar control and the effects on the thermal environment of a building. Energy and Buildings, 11: 181-199.

Jauregui E (1990/91) Influence of a large urban park on temperature and convective precipitation in a tropical city. Energy and Buildings, 15-16: 457-463.

Kuttler W, Strassburger A (1999) Air quality measurements in urban green areas - a case study. Atmospheric Environment, 33(24-25): 4101-4108.

Matzarakis A, Mayer H (1998) Investigations of urban climates thermal component in Freiburg, Germany. Preprints Second Urban Environment Symposium - 13th Conference on Biometerology and Aerobiology, Albuquerque, USA, American Meterological Society.

Matzarakis A, Mayer H, Iziomom E (1999) Applications of a universal thermal index: Physiological Equivalent Temperature. Int. J. Biometeorol., 43(2): 76-84.

Mayer H, Höppe P (1987) Thermal comfort on man in different urban environments. Theor. Appl. Climatol., 38: 43-49.

Oke T R (2004) Initial guidance to obtain representative meteorological observations at urban sites. Canada, WMO: 47. In Rosenberg N, Blad B, Verma S. 1983 - Microclimate. The biological environment. John Wiley \& Sons, New York

Oke T R (1989) The micrometeorology of the urban forest. Phil. Trans. R. Soc. Lond., B 324: 335349.

Oke T R (1987) Boundary layer climates. Routledge, London.

Saito I, Ishihara T, Katayama T (1990/91) Study of the effect of green areas on the thermal environment in an urban area. Energy Buildings, 15-16: 493-498.

Santamouris M (2001) The role of green spaces. In Santamouris M (ed.) Energy and climate in the built environment, Londres, James \& James Ltd: 145-159.

Spronken-Smith R A, Oke T R, Lowry H P (2000) Advection and the surface energy balance across an irrigated urban park. Int. J. Climatology, 20: 1033-1047. 
Spronken-Smith R A, Oke T R (1998) The thermal regime of urban parks in two cities with different summer climates. Int. J. Remote Sensing, 19: 2085-2104.

Upmanis H, Eliasson I, Lindqvist S (1998) The influence of green areas on nocturnal temperatures in a high latitude city Göteborg, Sweden. Int. J. Climatology, 18: 681-700.

Upmanis H, Eliasson I, Andersson-Sköld Y (2001) Case studies of the spatial variation of benzene and toluene concentrations in parks and adjacent built-up areas. Water, Air and Soil Pollution, 129: $61-81$.

Wilmers F (1988) Green for melioration of urban climate. Energy Buildings, 11: 289-299.

Yu C W, Hien N (2006) Thermal benefits of city parks. Energy Buildings, 38: 105-120. 